\title{
PEMAKAIAN ISTILAH BAHASA SANSKERTA PADA NAMA DIRI DI DALAM PRASASTI POH (827 ÇAKA): TINJAUAN PERSPEKTIF IDENTITAS
}

\section{THE USING OF SANSKRIT TERMS ON SOME PROPER NAMES IN POH INSCRIPTION (827 ÇAKA) : IDENTITY PERSPECTIVE}

\author{
Kayato Hardani \\ Mahasiswa Program Magister Arkeologi \\ Fakultas IImu Budaya Universitas Indonesia \\ k.thahar80@gmail.com
}

\begin{abstract}
Proper names is used as the individual differentiator and identity within the community. Parent in giving is often based on some motivation. Proper names can be analyzed linguistically because it contains elements of referential and vocative sign. Proper names are part of the human being, so that in every interaction within society, someone always conscious of his own identity for his own, other person and society interests. Diachronically the development of language, including the use of names can be traced back through written inscriptions. Proper names in Poh Inscription is a list of attendees (witnesses) who attended inauguration ceremony. Starting from this point, we can found the use of names on the Old Java period. This study aims to understand the construction and meaning of those proper names using an identity perspective. The method in this study is descriptive qualitative which begins with observing and analyzing proper names using Sanskrit language elements. This study concludes that Sanskrit names were closely related to motivation, encouragement, mindset, and new cultural responses in society. Proper names in Poh Inscription, if it is assumed to be garbhanama which was given by the parents during infancy to adulthood, then the direct selection using Sanskrit also affects the meaning chosen in their own name.
\end{abstract}

Keywords: Proper Name, Identity, Old Java, Sanskrit, Poh Inscription

\begin{abstract}
ABSTRAK
Nama diri secara umum adalah pembeda individu di dalam komunitas sekaligus sebagai identitas persona. Di dalam setiap pemberian nama sering didasari oleh motivasi dari pemberi nama (orang tua) kepada seorang anak yang baru dilahirkan. Nama diri dapat dianalisis secara linguistis karena di dalamnya mengandung unsur tanda yang berfungsi referensial sekaligus vokatif. Nama diri adalah sebagai bagian dari manusia itu sendiri, sehingga di dalam setiap interaksinya di dalam masyarakat, manusia senantiasa sadar akan identitas dirinya sendiri untuk berbagai kepentingannya sendiri, orang lain maupun masyarakat sebagai tempat ia hidup dan berinteraksi. Secara diakronis perkembangan bahasa, termasuk di dalamnya penggunaan nama diri dapat dilacak kembali kehadirannya melalui tinggalan tertulis berupa prasasti. Penulisan nama diri di dalam prasasti Poh secara tersurat hanya sebagai daftar nama hadirin (saksi) yang turut menghadiri upacara peresmian. Bertitik tolak dari hal tersebut dapat dijumpai penggunaan nama diri masa Jawa Kuna. Penelitian ini bertujuan untuk memahami konstruksi dan makna atas nama diri yang dijumpai di dalam Prasasti Poh dengan menggunakan perspektif identitas. Metode yang digunakan adalah deskriptif kualitatif yang diawali dengan mencermati dan menganalisis nama diri yang menggunakan unsur serapan Bahasa Sanskerta. Nama diri yang dijumpai di dalam Prasasti Poh apabila diasumsikan sebagai garbhanama yang tetap dipakai semenjak pertama kali diberikan oleh sang orang tua sewaktu bayi hingga dewasa, maka pemilihan dengan menggunakan Bahasa Sanskerta secara langsung juga berpengaruh pada makna yang dipilih atas nama diri mereka.
\end{abstract}

Kata Kunci : Nama Diri, Indentitas, Jawa Kuna, Bahasa Sanskerta, Prasasti Poh

$\begin{array}{ll}\text { Tanggal Masuk } & : 23 \text { Juli } 2018 \\ \text { Tanggal Diterima } & : 04 \text { Februari } 2019\end{array}$

Pemakaian Istilah Bahasa Sanskerta Pada Nama Diri Di Dalam Prasasti Poh (827 Çaka): 


\section{PENDAHULUAN}

Pemilihan nama atau pemberian nama diri pada hakekatnya suatu keputusan dan sikap yang hendak diungkapkan oleh orang tua kepada anaknya sebagai penyandang nama. Di dalam nama seringkali terkandung harapan, keinginan, doa, dan misi warisan yang diamanatkan kepada penyandang nama. Nama diri (antroponim) bukan hanya sebagai tanda atau ciri seseorang yang membedakannya dengan orang lain, tetapi telah menjadi semacam satu identitas pribadi seseorang karena mampu menjelaskan posisinya secara pribadi, sosial, bahkan keturunan secara genealogis.

Sahid Teguh Widodo (2001) dalam disertasinya yang berjudul Nama Diri Masyarakat Jawa mengungkapkan bahwa pemberian nama merupakan salah satu upaya seseorang di dalam memandang dunianya (wawasan jagad), yang menuntut agar saling mengkomunikasikan antara alam pikiran, cita-cita dengan lingkungan sosialnya. Lebih lanjut Teguh Widodo menyatakan bahwa setidaknya terdapat tiga sudut pandang mengenai sistem nama pada masyarakat Jawa modern. Adapun ketiga sistem nama tersebuat adalah (1) Static view, yaitu sudut pandang yang mengamati nama sebagai objek atau bentuk ujaran (verbal) yang statis, sehingga dapat dipisahpisahkan atau diuraikan serta diamati bagian-bagiannya secara mendetail dan menyeluruh dengan ilmu dan teori-teori bahasa. (2) Dynamic view, yaitu suatu pandangan yang melihat nama diri dalam keadaan bergerak dari waktu ke waktu, mengalami perubahan, perkembangan, dan pergeseran bentuk dan tata nilai yang melatarbelakanginya. (3) Strategic view, yaitu aspek strategis dari akumulasi fenomena dari segala bentuk perubahan dan perkembangannya, dan lebih jauh mengenai hubungan kebudayaan dengan bahasa, khususnya dalam nama diri (Widodo, 2001:162). Ketiga sudut pandang ini diharapkan telah mampu menangani berbagai bentuk permasalahan nama diri, baik dari segi kebahasaan, maupun dari aspek di luar bahasa, yaitu aspek sosiokulturalnya.

J.G de Casparis (1986) mengungkapkan bahwa penelitian terhadap nama diri yang bersumber dari prasasti dan naskah kuna dapat memberikan gambaran yang jelas mengenai masayarakat Jawa Kuna secara umum, baik itu di pusat kerajaan maupun di tingkat pedesaan. Nama diri juga memberikan data penting atas kelaskelas sosial, serta relasi antara pusat dengan daerah dalam hal penetrasi pengaruh kebudayaan India (termasuk di dalamnya agama) hingga jauh menyentuh ke wilayah pedesaan hingga membentuk suatu konvensi sebagai bagian dari privasi satu keluarga di dalam pemberian nama terhadap bayi yang baru dilahirkan (Casparis, 1986:8). Secara diakronis penggunaan nama diri pada masyarakat Jawa pada masa lampau dapat dilacak kembali melalui tinggalan arkeologis berupa prasasti. Di dalam tulisan ini digunakan data Prasasti Poh yang berangka tahun 827 Saka (905 Masehi). Prasasti ini menarik untuk dibahas karena di dalamnya dijumpai nama diri pejabat hingga warga biasa (anak wanua) sebanyak 140 orang dan merupakan jumlah saksi yang lebih banyak apabila dibanding prasasti lain yang berkenaan dengan penetapan sima. 

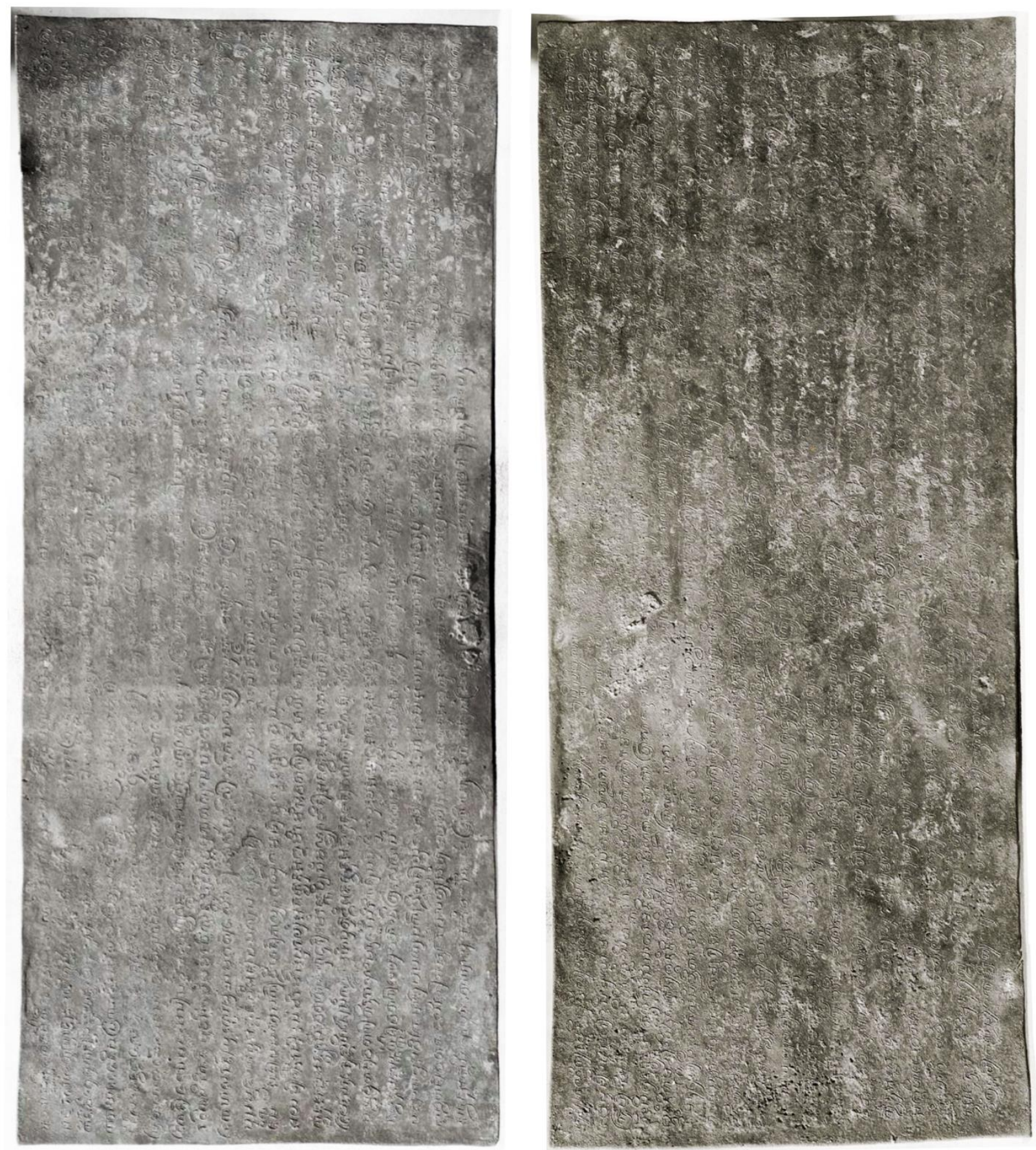

Gambar 1. Prasasti Poh Lempeng 1A (kanan) dan Lempeng 2B (kiri)

(Dok. digitalcollections.universiteitleiden.nl) 
Prasasti Poh atau Prasasti Randoesari I pertama kali ditelaah secara kritis oleh W.F Stutterheim pada tahun 1940. Prasasti Poh merupakan 2 lempeng prasasti tembaga yang ditemukan di dukuh Plembon, Kelurahan Randusari, Gondangwinangun, Klaten. Dinamai sebagai prasasti Poh karena berisi tentang penetapan wanua Poh menjadi sima yang dikeluarkan pada masa pemerintahan Rakai Watukura Dyah Balitung.

Penetapan suatu wilayah menjadi sima dapat merupakan anugerah raja kepada seseorang yang telah berjasa atau untuk memelihara suatu bangunan suci. Pemberian status sima juga dilakukan agar wilayah yang kurang penting menjadi lebih menarik bagi para petani yang pada akhirnya dapat memperluas pemukiman yang sudah mantap menjadi wilayah yang strategis (Christie,1989a:6). Selain itu, penetapan sebagai sima juga dimaksudkan sebagai upaya pengembangan wilayah. Pengembangan wilayah adalah dengan pengembangan pemukiman desa atau watak atau juga berupa pengembangan wilayah pertanian atau tegalan (Tjahjono dan Rangkuti, 1998:46).

\begin{tabular}{llr}
\multicolumn{1}{c}{ Pada } & setiap & upacara \\
penetapan & sima & selalu \\
menghadirkan & pejabat & beserta
\end{tabular} sejumlah warga desa atau anak wanua sebagai saksi yang disertai dengan pesta dan diakhiri dengan pemberian pasek-pasek sebagai persembahan yang berwujud bahan pakaian, uang emas dan perak. Khusus bagi hadirin dari kalangan warga desa seringkali berasal dari desa sekitar wilayah (desa tpi i siring) yang ditetapkan sebagai sima. Pesta di dalam sebuah upacara sima semacam ini mengindikasikan gejala arkaik pesta jasa khas Nusantara. Di dalam Prasasti Poh ini pula kita menjumpai nama-nama pejabat dan warga desa yang menghadiri dalam pesta sekaligus sebagai penerima pasek-pasek tersebut.

Upacara penetapan sima sebagaimana yang dituliskan di dalam prasasti dapat diamati sejumlah gejala sosial yang membeku dalam teks prasasti. Hal tersebut lebih berkenaan dengan sifat prasasti sebagai wujud budaya materi yang menghadirkan prasasti sebagai artefak yang memiliki makna dan telah dihayati bersama oleh kelompok sosial atau komunitas masyarakat. Penggunaan bahasa di dalam prasasti telah menjadikan prasasti sebagai budaya materi yang di dalamnya mengandung ide gagasan.

Salah satu hal yang menarik dijumpai di dalam gejala kebahasaan prasasti adalah penggunaan kosakata serapan Bahasa Sanskerta pada prasasti abad ke-9 hingga 10 Masehi. Nama diri (antroponimi) yang menggunakan unsur kata pinjaman Bahasa Sanskerta menjadi gejala kebudayaan yang menarik. Nama diri adalah nama yang diberikan semenjak lahir (garbhanama) oleh orang tua bayi yang seringkali menunjukkan posisi seseorang secara hirarki dalam stratifikasi sosial masyarakat masa itu. Pemarkah yang sering dipakai sebagai pembeda tersebut adalah kehadiran partikel persona (dyah, pu, si dan sang) yang muncul di depan nama diri.

Pada masa Jawa Kuna terdapat beberapa istilah di dalam Bahasa Jawa Kuna yang berkenaan dengan istilah "nama diri" yang dijumpai di dalam naskah dan prasasti, yakni aran, nāma, kěkasir atau kasir-kasir, pañji, puspapāta, pasěńgahan atau pasańguhan (Casparis, 1986: 10) 
Bermula dari hal tersebut maka sangat menarik untuk dikaji pemakaian nama diri pada masyarakat Jawa Kuna sebagaimana yang terekam di dalam Prasasti Poh, khususnya pemakaian nama diri yang menggunakan unsur serapan Bahasa Sanskerta sebagai upaya menunjukkan identitas personal sebagai bagian dari masyarakat masa itu. Dengan demikian dapat dipahami mengenai pemakaian nama diri, baik dari segi kebahasaan, maupun dari aspek di luar bahasa (aspek sosio-kultural) yang pernah terjadi di Jawa pada abad ke-9 Masehi.

\section{METODE}

Penelitian ini bertujuan untuk memahami konstruksi dan makna nama diri yang dijumpai di alam Prasasti Poh dengan menggunakan perspektif identitas. Metode yang digunakan adalah deskriptif kualitatif dengan mencermati dan menganalisis nama diri yang dijumpai di dalam Prasasti Poh. Di dalam prasasti tersebut dijumpai 140 nama diri dari pejabat kerajaan, watak, wanua serta saksi non pejabat. Dari 140 orang tersebut terindikasi ada 35 orang yang menggunakan nama diri yang secara etimologis merupakan unsur kosa kata pinjaman dari Bahasa Sanskerta. Untuk melacak kembali makna leksikal dari unsur kata pinjaman tersebut digunakan uraian etimologi yakni studi asal kata serta perubahannya dalam bentuk dan makna. Untuk menemukan sejarah kata atau etimologi, sumber terbaik adalah kamus, sebab kamus ditulis dengan menggunakan prinsipprinsip historis (Crystal, 1992:340). Di dalam penelitian ini kamus Bahasa Sanskerta yang menjadi acuan adalah Sanskrit-English Dictionary yang disusun oleh Arthur A. MacDonnel (1893).

Nama-nama diri yang secara leksikal berasal dari Bahasa Sanskerta kemudian dilakukan analisis melalui perspektif identitas. Penerapan perspektif identitas di dalam nama diri adalah untuk menginterpretasikan bagaimana masyarakat masa itu mengidentifikasikan, acuan serta pembedaan seseorang dengan orang lain dalam komunitas. Hal yang terpenting di dalam memandang nama diri yang menggunakan unsur Bahasa Sanskerta adalah adanya pemahaman bahwasanya peminjaman unsur Bahasa asing merupakan ciri kedinamisan suatu kebudayaan yang dicirikan dengan mengalami perkembangan di dalam unsur-unsurnya.

\section{HASIL PENELITIAN}

\section{Konsep Tentang Nama Diri}

Nama diri apabila ditinjau dari sisi kebahasaan merupakan satuan lingual sebagai suatu tanda. Tanda merupakan kombinasi dari konsep (penanda) dan bentuk yang tertulis atau diucapkan. Dalam hal ini nama diri berfungsi sebagai penanda identitas satu individu yang membedakan dengan individu lain. Nama dibuat untuk dipakai dan diujarkan demi kepraktisan dalam hidup sehari-hari. Pemberian nama diri merupakan bagian wawasan jagad atau world view yakni cara manusia memandang kosmos 'alam semesta' dan lingkungan sosial budayanya melalui perilaku dan ideidenya yang dituangkan dalam bahasa. Salah satu ide itu tersirat dalam praktek pemberian nama sebagai manifestasi kondisi psikologis masyarakatnya pada tataran makro, yakni bagaimana 
mencitrakan dirinya (inner world) dan bagaimana memunculkan citranya ke dunia luar, yang selanjutnya merefleksikan struktur berfikir dari warganya. Pola pikir seperti ini pada akhirnya akan turut menentukan struktur sosial budaya masyarakat dan juga dapat menjadi salah satu indikator idieologis suatu kelompok masyarakat, yang mencakup nilainilai yang dianut (kepatutan, baikburuk, pantas-tidak pantas) (Kosasih, 2010:2).

$$
\text { Secara umum pemilihan }
$$

nama diri di dalam berbagai kebudayaan memiliki kesamaan konseptual yakni berkisar tentang harapan orang tua yang mengandung kemuliaan, kepahlawanan atau keindahan mereka kepada sang anak. Mengubah nama seseorang berarti mengubah identitas seseorang. Nama diri dapat mengungkapkan tentang kesukaan atau ketidaksukaan orang, mode dan tren, serta kecenderungan agama dan politik, dan dengan demikian studi tentang nomenklatur nama diri dalam berbagai (Schimmel,1989: ix).

Penggunaan nama diri di dalam suatu masyarakat juga turut mengalami perubahan sejalan perjalanan sejarah. Hal ini disebabkan nama diri memiliki kaitan yang erat dengan bidang linguistik, sosiolinguistik dan semantik, sehingga sangat memungkinkan untuk terjadi perubahan. Secara diakronis penggunaan nama diri untuk masyarakat Jawa Kuna dapat dilacak keberadaannya melalui tinggalan prasasti. Dengan dijumpainya nama diri di dalam prasasti bisa dianalisis atas bahasa yang tersurat serta dapat menggambarkan alam pikiran pemberian nama diri di masa itu. Sebagai bagian dari bahasa, nama diri merupakan gejala budaya yang bersifat dinamis akan selalu mengalami perubahan dan pengayaan yang dipengaruhi konteks sejarah yang melingkupinya. Pada abad ke-10 Masehi konteks kebudayaan yang dominan adalah agama Hindu dan Buddha di samping dominasi unsur asli Austronesia yang tidak dapat diabaikan keberadaannya. Selama ini dipahami jika pengaruh India hanyalah sebatas bersentuhan dengan kalangan rajya (bangsawan kerajaan) sebagai pusat kebudayaan dan intelektualitas. Adapun kalangan rakyat kebanyakan sekedar menerima rembesan pengaruh kebudayaan. Hipotesis semacam ini seringkali diibaratkan riak air yang timbul dari jatuhnya batu di dalam kolam. Secara sederhana digambarkan gelombang akan lebih kuat yang terletak di dekat titik jatuhnya batu yang kemudian gelombang ini semakin melemah menjauhi titik pusat. Meski hal semacam ini masih perlu diteliti lebih jauh untuk kasus kebahasaan.

Nama diri dari masa sebelum meresapnya pengaruh Hindu dan Buddha dapat dicermati di dalam prasasti-prasasti tertua yang pernah dijumpai di Nusantara. Sebagaimana yang terlihat di dalam prasasti yupa di Kutai yang menyebut genealogi raja Kundungga yang berputra Aswawarman, dan Aswawarman juga berputra yang bernama Mulawarman. Di dalam prasasti tersebut Aswawarman disebut sebagai pendiri keluarga kerajaan atau wangsakarta, bukan Kundungga yang dianggap sebagai raja pertama. Nama-nama yang muncul di dalam prasasti yupa seperti Kundungga, Aswawarman dan Mulawarman menunjukkan adanya perbedaan pemakaian nama diri dalam 3 generasi. Generasi pertama adalah Kundungga yang mengindikasikan 
sebuah nama khas asli Austronesia. Berbeda dengan generasi kedua dan ketiga yang menggunakan nama diri yang secara etimologis mengacu pada pengaruh India. Kundungga dapat dianggap sebagai orang yang pertama kali menyentuh budaya India tetapi belum secara penuh menganut pengaruh baru tersebut. Kemudian pada generasi selanjutnya yakni anak dan cucunya sudah sepenuhnya menganut pengaruh India, sehingga menyamakan dirinya sederajat dengan orang India yang tergolong di dalam kasta-kasta sejak dilahirkan.

Fakta yang dijumpai dari prasasti Yupa menunjukkan bahwa kedatangan pengaruh India di Nusantara juga membawa perubahan sekaligus pengayaan dalam proses sistem pemberian nama. Di dalam tradisi Weda dikenal adanya upacara namakarana yang dilakukan pada usia bayi 10-12 hari atau pada hari lain yang dianggap baik (Casparis, 1986:9). Pemberian nama juga didasarkan naksatra yang sedang berlangsung. Naksatra merupakan konstelasi bintang sebanyak 27 yang pada dasarnya mengikuti pergerakan bulan, matahari dan planet-planet (Magli, 2009:105).

Di dalam tradisi Hindu Bali terdapat upacara kelahiran yang disebut Jatakarma Samskara yang di dalam upacara ini sang ayah diminta menyentuh bayinya yang baru lahir sambil membacakan mantra pemberkatan di telinga, menyampaikan harapan agar bayi berumur panjang dan menjadi anak pandai. Meski demikian pada masyarakat jawa kuna keberadaan upacara pemberian nama belum dapat diidentifikasikan. Namun jika akan dianalogikan dengan tradisi Hindu Bali harus tetap hati-hati, karena pada masa Jawa Kuna pembeda nama sebagai penanda kasta tidak sejelas Bali sebagaimana terlihat di dalam nama diri yang disandang. Pelapisan sosial pada masyarakat Jawa Kuna secara umum didasarkan menjadi empat aspek yakni umur, jenis kelamin, pemilikan harta, kedudukan dalam pemerintahan dan warna atau kasta (Rahardjo, 2011:84). Lebih jauh dikatakan oleh Rahardjo bahwa pelapisan pada tingkat luar kerajaan terdapat struktur sosial di pedesaan atau karaman yang dibedakan pula atas aspek umur yaitu "tua" dan "muda'. Sehingga muncul istilah lain dalam penyebutan penduduk desa yakni raray dan anak wanua. Dari data Prasasti Poh yang dipakai dalam tulisan ini terlihat adanya indikasi perbedaan pelapisan sosial yang tampak dalam penggunaan partikel persona yakni si, sang, pu dan dyah yang secara jelas menampakkan perbedaan persona secara genealogis. Partikel penanda yang berupa dyah adalah partikel khusus garbhanama raja saja. Sedangkan orang non famili kerajaan hanya berhak menggunakan partikel si, sang dan pu. Jan Wisseman Christie (1989b) berpendapat bahwa kemunculan kosakata Sanskerta di dalam nama diri warga wanua pada abad ke-9 Masehi adalah disebabkan oleh adanya tradisi wayang yang mengambil cerita tentang Ramayana dan Mahabharata dimana tradisi seni tersebut menjadi kendaraan transmisi penyebaran kosakata dari bahasa Sanskerta. la mendasarkan pendapatnya tersebut pada temuan prasasti Sangsang (907 M) (Christie (1989b:34).

Terlepas dari pelapisan sosial di dalam masyarakat Jawa Kuna pada waktu itu, agaknya menarik untuk memandang nama diri (antroponim) penduduk desa (anak wanua) yang secara kultural jauh dari 
budaya keraton, yakni nama diri yang mencirikan pemakaian istilah dari Bahasa Sanskerta. Penduduk desa pada waktu itu turut menjadi bagian dari peradaban dengan menempatkan identitasnya sendiri yakni dengan pemilihan nama diri. Nama diri dengan kosa kata pinjaman Bahasa Sanskerta lebih mempunyai makna berbeda apabila ditinjau dari sisi keyakinan religius pada masa itu yakni Hindu dan Buddha. Nama diri mempunyai tiga fungsi yang saling berkait yakni sebagai identifikasi, acuan dan pembeda (Zabeeh,1968:59).

\section{Nama Diri Hadirin Upacara Sima Wanua Poh Tahun 907 Masehi}

Nama diri dalam masyarakat Jawa Kuna yang terlihat dalam prasasti menampakkan kecenderungan gejala patriarkhi dalam kehidupan sosialnya. Selain itu juga tampak adanya indikasi penggunaan alur ayah sebagai penanda terlihat dari prosentase penggunaan kata rama ni (ayahnya) lebih besar dibanding penggunaan inang ni (ibunya). Menariknya kata 'rama' secara etimologis berasal dari Bahasa Sanskerta yang berarti ayah, kata pinjaman ini kemudian disejajarkan dengan kosakata asli Jawa 'inang' yang pada dasarnya adalah bentuk retensi dari kosakata Proto Austronesia (PAN) *inan. Adapan bentuk 'ni' adalah bentuk pewarisan Bahasa Jawa Kuna dari bahasa PAN sebagai penunjuk konstruksi genetif (pemilik). Bentuk ' $n i$ ' terjadi melalui pelesapan bunyi akhir bentuk Austronesia *nia
(Mahsun, 2010: 202). Bentuk ini pula yang masih bertahan pada masa Jawa modern 'ne' seperti dalam kata bapakne (ayahnya).

Bermula dari nama para hadirin yang hadir sebagai saksi di dalam upacara penetapan sima dapat diketahui fakta-fakta sosial yang hidup berkembang pada masa itu. Baik itu saksi dari kalangan pejabat kerajaan, pejabat watak maupun penduduk desa/seniman. Di dalam Prasasti Poh terlihat adanya beberapa penggunaan formula nama untuk mengidentifikasi persona yang berbeda dan menunjukkan pengelompokan-pengelompokan tertentu. Penentuan formula-formula tersebut lebih didasarkan pada penyebutan partikel penyebut yang secara langsung ditulis di depan nama diri. Berikut disajikan tabel tentang jenis formula yang dijumpai di dalam Prasasti Poh (Tabel 1).

Selain itu secara kuantitatif formula tersebut apabila diklasifikasikan berdasar kategori jabatan administratif kerajaan, yakni pejabat kerajaan, pejabat tingkat watak, pejabat tingkat wanua, dan terakhir non pejabat (saksi dan seniman) akan diperoleh data sebagai berikut (Tabel 2). Selain itu juga disajikan tabel nama diri keseluruhan saksi yang jadir di dalam upacara penetapan sima yakni sebanyak 140 orang. Tabel-tabel tersebut dibedakan menjadi 4 kategori yakni pejabat kerajaan, pejabat watak, pejabat wanua dan non pejabat (Tabel 3, Tabel 4, Tabel 5 dan Tabel 6). 
Tabel 1. Jenis Formula Partikel Penyebut Nama Diri Prasasti Poh

\begin{tabular}{|c|c|c|}
\hline No. & Formula & Keterangan \\
\hline 1. & Formula "Dyah..." & $\begin{array}{l}\text { Formula ini hanya dijumpai satu orang dalam Prasasti } \\
\text { Poh yakni dipakai oleh Sri Maharaja. Dari hal tersebut } \\
\text { menunjukkan bahwa 'dyah' hanya dipakai untuk } \\
\text { kalangan raja beserta anak (lelaki ?) keturunannya. }\end{array}$ \\
\hline 2. & Formula “Pu ..." & $\begin{array}{l}\text { Diperkirakan formula ini dipakai oleh kalangan } \\
\text { terdidik setidaknya dapat membaca menulis karena } \\
\text { dijumpai beberapa orang citralekha dengan gelar ini. } \\
\text { Selain itu juga dijumpai wanita (pejabat kerajaan) yang } \\
\text { menggunakan formula ini. }\end{array}$ \\
\hline 3. & Formula "Pu... rama ni..." & $\begin{array}{l}\text { Formula ini hanya dijumpai } 1 \text { orang di struktur pejabat } \\
\text { watak. Formula ini diperkirakan sebagai variasi dari } \\
\text { formula kedua. Meski demikian adanya pembedaan } \\
\text { penulisan di dalam prasasti tentu terdapat alasan yang } \\
\text { melatarbelakangi. }\end{array}$ \\
\hline 4. & Formula "Si..." & $\begin{array}{l}\text { Formula ini sepertinya juga merupakan penanda } \\
\text { stratifikasi sosial yang setara dengan formula "pu". } \\
\text { Beberapa pejabat setingkat watak menunjukkan jika } \\
\text { jabatan antara seseorang dengan formula "pu" setara } \\
\text { dengan seseorang dengan formula "si". }\end{array}$ \\
\hline 5. & Formula "si... rama ni ..." & $\begin{array}{l}\text { Secara sekilas formula ini hampir mirip dengan } \\
\text { formula "si.." namun dilihat dari perbedaan kuantitas } \\
\text { tampak jika formula ini lebih banyak dipakai di } \\
\text { kalangan pejabat wanua. Tampaknya formula ini untuk } \\
\text { menunjuk pembeda jenis kelamin sebagai lelaki. }\end{array}$ \\
\hline 6. & Formula "si... inang ni ... & $\begin{array}{l}\text { Formula ini hanya dijumpai pada pejabat setingkat } \\
\text { wanua. Diperkirakan formula ini untuk menunjuk } \\
\text { pembeda jenis kelamin sebagai perempuan }\end{array}$ \\
\hline 7. & Formula "sang..." & $\begin{array}{l}\text { Formula ini dijumpai dengan diikuti nama dan jenis } \\
\text { jabatan }\end{array}$ \\
\hline 8. & Formula “dapunta... & $\begin{array}{l}\text { Formula ini hanya dijumpai satu kali saja sebagai } \\
\text { pejabat watak }\end{array}$ \\
\hline
\end{tabular}

Keterangan: tabel ini dibuat penulis berdasarkan data yang digunakan 
Tabel 2. Jenis Jumlah pejabat/nonpejabat ditinjau dari formula

\begin{tabular}{llccccc}
\hline No. & Formula & $\begin{array}{c}\text { Pejabat } \\
\text { kerajaan }\end{array}$ & $\begin{array}{c}\text { Pejabat } \\
\text { watak }\end{array}$ & $\begin{array}{c}\text { Pejabat } \\
\text { wanua }\end{array}$ & $\begin{array}{c}\text { Non } \\
\text { pejabat }\end{array}$ & Jumlah \\
\hline 1. & Dyah... & 1 & - & - & - & $\mathbf{1}$ \\
\hline 2. & Pu... & 15 & 18 & 1 & - & $\mathbf{3 4}$ \\
\hline 3. & Pu...rama ni.. & - & 1 & - & - & $\mathbf{1}$ \\
\hline 4. & Si... & - & 17 & 14 & 4 & $\mathbf{3 6}$ \\
5. & Si...rama ni... & - & 9 & 37 & 5 & $\mathbf{5 2}$ \\
6. & Si...inang ni... & - & - & 6 & - & $\mathbf{6}$ \\
7. & Sang... & - & 1 & - & - & $\mathbf{1}$ \\
8. & Dapunta... & - & 1 & - & - & $\mathbf{1}$ \\
\hline
\end{tabular}

Sumber: W.F. Stutterheim, 1940

Tabel 3. Nama diri pejabat kerajaan

\begin{tabular}{|c|c|c|c|}
\hline No. & Garbha Nama & $\begin{array}{l}\text { Lempeng/ } \\
\text { baris }\end{array}$ & Kedudukan/jabatan \\
\hline 1. & dyah balitung & Ib. 2 & çrī mahārāja \\
\hline 2. & pu tammĕr & Ib.6 & nini haji rakai wwatan \\
\hline 3. & pu wīrawikrama & Ib.7 & rakai halu \\
\hline 4. & pu wariga & Ib. 8 & rakai sirikan \\
\hline 5. & pu kutak & Ib. 8 & rakai wka \\
\hline 6. & pu asangā & Ib.8 & sang pamagat tiruan \\
\hline 7. & pu tlodung & Ib.9 & rakai halaran \\
\hline 8. & pu puñjang & Ib.9 & rakai palarhyang \\
\hline 9. & pu cakra & Ib.9 & Manghuri \\
\hline 10. & pu çiwadhyāna & Ib.9 & Pangkur \\
\hline 11. & pu sūryya & Ib.9 & Tawān \\
\hline 12. & pu krmna & Ib.9 & Tirip \\
\hline 13. & pu dapit & Ib. 9 & Wadihati \\
\hline 14. & pu samwrda & Ib. 10 & Makudur \\
\hline 15. & pu bnat & Ib. 10 & Kiniwang \\
\hline 16. & pu tundung & Ib. 11 & sang kiniwang anakbi \\
\hline
\end{tabular}

Sumber: W.F. Stutterheim, 1940 
Tabel 4. Nama diri pejabat tingkat watak

\begin{tabular}{|c|c|c|c|}
\hline No. & Garbha Nama & $\begin{array}{c}\text { Lempeng/ } \\
\text { baris }\end{array}$ & Kedudukan/jabatan \\
\hline 1. & pu rayung & Ib.12 & sang miramirah \\
\hline 2. & pu dhanada & Ib. 12 & sang halaran \\
\hline 3. & pu mankai & Ib. 12 & sang tangkilsugih \\
\hline 4. & pu tunggang & Ib. 14 & sang kandamuhi \\
\hline 5. & pu maněsor & Ib. 14 & citralaikhā sang watuwarani \\
\hline 6. & pu damodara & Ib.14 & parujarri halu sang wimga \\
\hline 7. & pu ayuddha & Ib. 15 & sirikan sang hujunggaluh \\
\hline 8. & pu samudra & Ib. 15 & citralekhā sang dharmmasinta \\
\hline 9. & pu danu & Ib. 15 & parujarri wka sang wiridih \\
\hline 10. & pu gowinda & Ib. 16 & citralekhā sang halangmanuk \\
\hline 11. & dapunta katimamang & Ib. 16 & parujar i tiruan sang sumudan \\
\hline 12. & pu batu & Ib. 17 & parujarri halaran sang rawanu \\
\hline 13. & pu laksana & Ib. 17 & parujarri dalinan sang waryyang \\
\hline 14. & pu baka & Ib. 18 & parujarri palarhyang sang tumpal \\
\hline 15. & pu gupura & Ib. 18 & parujarri manghuri sang ranugra \\
\hline 16. & pu samodaya & Ib. 18 & parujarri wka sang dadalan \\
\hline 17. & pu rāghū & Ib. 19 & parujarri tirip sang rapadang \\
\hline 18. & si ranghal & IIa.1 & parujar sang mānak i pangkur \\
\hline 19. & si sañjaya & IIa.1 & parujar sang mānak i pangkur \\
\hline 20. & si masusū & IIa.1 & parujar sang mānak i tawan \\
\hline 21. & si cangka & IIa.2 & parujar sang mānak i tawan \\
\hline 22. & si lakā & IIa.2 & parujar sang mānak i tirip \\
\hline 23. & si pārthawa & IIa.2 & i wadihati lumaku manuçuk \\
\hline 24. & sang uttara & IIa.3 & i makudur lumaku manuçuk \\
\hline 25. & pu mana & IIa.4 & pangurang i hino \\
\hline 26. & si naitra & IIa.4 & pangurang i halu \\
\hline 27. & si rapilang & IIa.6 & parujar rakai wwatan \\
\hline 28. & pu kaiçawa & IIa.7 & juru ni mangrangkat i wwatan \\
\hline 29. & si pangadaggan & IIa.8 & sang rataji mangilala sukadbā i poh \\
\hline 30. & si lagal & IIa.8 & juruning kanayakān i kiniwang \\
\hline 31. & si çala rama ni barubuh & IIa.9 & pangurang sang kiniwang \\
\hline 32. & si gasyak rama ni gawang & IIa.9 & pangurang sang kiniwang \\
\hline 33. & si sangkhara rama ni widyū & IIa.10 & pangurang sang kiniwang \\
\hline 34. & si prajña & IIa.11 & pangurang sang kiniwang \\
\hline 35. & si purul rama ni wudyang & IIa.11 & pangurang sira kring \\
\hline 36. & si gunung rama ni pakudān & IIa.11 & pangurang sira kring \\
\hline 37. & pu mamwi rama ni manojña & IIa.12 & pangurang sang manimpiki \\
\hline 38. & si drping rama ni pangalah & IIa.12 & patih i kiniwang nayaka sang rakawu \\
\hline
\end{tabular}

Pemakaian Istilah Bahasa Sanskerta Pada Nama Diri Dí Dalam Prasasti Poh (827 Çaka): 


\begin{tabular}{llll}
\hline 39. & si gĕgĕl rama ni tunggang & IIa.13 & patih i kiniwang nayaka sang rakawu \\
40. & si katimahā & IIa.13 & patih lampuran i kawu \\
41. & si ralua & IIa.14 & patih lampuran \\
42. & si lmahhidi & IIa.14 & patih lampuran \\
43. & si rawakan & IIa.14 & parujar ning patih \\
44. & si wahugya rama ni purul & IIa.15 & parujar ning patih \\
45. & si barut rama ni lucir & IIa.15 & wahuta i kiniwang sira sěang \\
46. & si cangkir & IIa.16 & wahuta lampuran \\
\hline 47. & si purul & IIa.17 & wahuta lampuran \\
\hline
\end{tabular}

Sumber: W.F. Stutterheim, 1940

Tabel 5. Nama diri pejabat tingkat wanua

\begin{tabular}{|c|c|c|c|}
\hline No. & Garbha Nama & $\begin{array}{l}\text { Lempeng/b } \\
\text { aris }\end{array}$ & Kedudukan/jabatan \\
\hline 1. & si gupi rama ni jawil & IIa. 18 & sang tuha banua \\
\hline 2. & si rĕmma rama ni gantih & IIa.18 & Kalima \\
\hline 3. & si sandak rama ni libat & IIa.18 & Juru \\
\hline 4. & si wirat rama ni nunggū & IIa.18 & Juru \\
\hline 5. & si anggal & IIa.18 & Juru \\
\hline 6. & si kuyū & IIa.18 & Juru \\
\hline 7. & si krit & IIa.19 & parujar ning juru \\
\hline 8. & si sĕgěl rama ni basawa & IIa.19 & patngahan ning juru \\
\hline 9. & si suk rama ni turus & IIa.19 & tuha kalang \\
\hline 10. & si rutut rama ni buhara & IIa.19 & Winkas \\
\hline 11. & si tato rama ni sāgi & IIa.19 & tuha guçali \\
\hline 12. & si kandit rama ni butěl & IIb.1 & Gusti \\
\hline 13. & si kanděl rama ni duduk & IIb.1 & Gusti \\
\hline 14. & si pula rama ni waruwu & IIb.1 & Gusti \\
\hline 15. & si kirim rama ni gimuh & IIb.1 & Gusti \\
\hline 16. & si cangal rama ni cakang & IIb.1 & Gusti \\
\hline 17. & si jamah rama ni baisus & IIb. 2 & Gusti \\
\hline 18. & si mula rama ni buddhi & $\mathrm{IIb} .2$ & Parujar \\
\hline 19. & si gamana & IIb. 2 & Parujar \\
\hline 20. & si kabya rama ni sima & IIb.2 & rāma maratā \\
\hline 21. & $\begin{array}{l}\text { si gading rama ni } \\
\text { hampalung }\end{array}$ & IIb. 2 & rāma maratā \\
\hline 22. & si karyyut rama ni capah & $\mathrm{IIb} .2$ & rāma maratā \\
\hline 23. & si cunrěng rama ni krap & IIb. 2 & rāma maratā \\
\hline 24. & si pande rama ni hindang & IIb.3 & rāma maratā \\
\hline 25. & $\begin{array}{l}\text { si tangkirang rama ni } \\
\text { tambilung }\end{array}$ & IIb. 3 & rāma maratā \\
\hline 26. & si katak rama ni pawan & $\mathrm{IIb} .3$ & rāma maratā \\
\hline 27. & si pandĕt rama ni bantĕr & IIb.3 & rāma maratā \\
\hline 28. & si lingir rama ni wĕlĕt & IIb.3 & rāma maratā \\
\hline 29. & si brakara rama ni kuruh & IIb.3 & rāma maratā \\
\hline
\end{tabular}




\begin{tabular}{|c|c|c|c|}
\hline 30. & si kudyal rama ni tarambal & IIb.3 & rāma maratā \\
\hline 31. & si mangga rama ni garga & IIb.3 & rāma maratā \\
\hline 32. & si guruntung rama ni tatuk & IIb.4 & rāma maratā \\
\hline 33. & si sādha rama ni dhūta & $\mathrm{IIb} .4$ & rāma maratā \\
\hline 34. & si...inang ni pingul & IIb.4 & pinda rainanta \\
\hline 35. & si tiris inang ni gantih & IIb. 4 & pinda rainanta \\
\hline 36. & si wirikan inang ni jawil & IIb.4 & pinda rainanta \\
\hline 37. & si jabwah inang ni çuddha & $\mathrm{IIb} .4$ & pinda rainanta \\
\hline 38. & si limwayā inang ni kamman & $\mathrm{IIb} .4$ & pinda rainanta \\
\hline 39. & si wulakan inang ni gading & $\mathrm{IIb} .5$ & pinda rainanta \\
\hline 40. & si kārigna & $\mathrm{IIb} .5$ & rarāma bhumana \\
\hline 41. & si darinī & $\mathrm{IIb} .5$ & rarāma bhumana \\
\hline 42. & si rumpuk & IIb.5 & rarāma bhumana \\
\hline 43. & si jaway & $\mathrm{IIb} .5$ & Wěrěwěrěh \\
\hline 44. & si baryyut & $\mathrm{IIb} .5$ & Wěrěwĕrĕh \\
\hline 45. & si wawā rama ni gampwar & IIb.6 & tuha banua \\
\hline 46. & si pyang rama ni mundu & IIb.6 & Juru \\
\hline 47. & si banya rama ni wawa & IIb.7 & tuha banua \\
\hline 48. & si kasisap & IIb.7 & tuha banua \\
\hline 49. & si niti rama ni wdung & $\mathrm{IIb} .8$ & tuha kalang \\
\hline 50. & si sangkhara & $\mathrm{IIb} .8$ & tuha kalang \\
\hline 51. & si ndandok rama ni hasin & $\mathrm{IIb} .8$ & mangmit sawah haji \\
\hline 52. & si rapöng & IIb.10 & Manulup \\
\hline 53. & pu wilut & IIb.11 & sang madāng/ sang mangla \\
\hline 54. & si janar & IIb.11 & sang madāng/ sang mangla \\
\hline 55. & si bayur & IIb.11 & sang madāng/ sang mangla \\
\hline 56. & dapunta piwwi & IIb.12 & sang mūlawuddha huluwras \\
\hline 57. & si lañot rama ni mulat & IIb.13 & sang mūlawuddha huluwras \\
\hline
\end{tabular}

Sumber: W.F. Stutterheim, 1940

Tabel 6. Nama diri saksi nonpejabat (warga biasa)

\begin{tabular}{llll}
\hline No. & Garbha Nama & $\begin{array}{c}\text { Lempeng/b } \\
\text { aris }\end{array}$ & \multicolumn{1}{c}{ Kedudukan/jabatan } \\
\hline 1. & si brita rama ni taram & IIb.6 & rāma tpi siring milu sākçī \\
\hline 2. & si palwak rama ni turubut & IIb.6 & rāma tpi siring milu sākçī \\
3. & si wangun rama ni wira & IIb.6 & rāma tpi siring milu sākçī \\
\hline 4. & syuha rama ni wakul & IIb.14 & Mapadahi \\
\hline 5. & si wicar rama ni wisama & IIb.14 & Marěgang \\
\hline 6. & si mala & IIb.15 & Matapukan \\
\hline 7. & si parasi & IIb.15 & Matapukan \\
\hline 8. & si lugundung & IIb.16 & Mabañol \\
\hline 9. & si kulika & IIb.16 & Mabañol \\
\hline
\end{tabular}

Sumber: W.F. Stutterheim, 1940

Pemakaian Istilah Bahasa Sanskerta Pada Nama Diri Di Dalam Prasasti Poh (827 Çaka): 
Tabel 7. Prosentase pemakaian nama diri dengan kosakata bahasa Sanskerta pada pejabat dan non pejabat

\begin{tabular}{lcccc}
\hline & $\begin{array}{c}\text { Pejabat } \\
\text { kerajaan }\end{array}$ & $\begin{array}{c}\text { Pejabat } \\
\text { watak }\end{array}$ & $\begin{array}{c}\text { Pejabat } \\
\text { wanua }\end{array}$ & $\begin{array}{c}\text { Non } \\
\text { pejabat }\end{array}$ \\
$\begin{array}{l}\text { Jumlah total pejabat/nonpejabat yang } \\
\text { hadir sebagai saksi }\end{array}$ & 16 & 47 & 68 & 9 \\
$\begin{array}{l}\text { Jumlah pejabat/non pejabat yang } \\
\text { memakai nama diri kosakata bahasa }\end{array}$ & 6 & 20 & 7 & 2 \\
Sanskerta & & & \\
\hline \\
Prosentase dari keseluruhan saksi
\end{tabular}

Keterangan : Tabel ini dibuat penulis berdasarkan data yang digunakan

Tabel 8. Prosentase pemakaian nama diri dilihat dari formula yang dipakai

\begin{tabular}{lccc}
\hline Formula & Jumlah total & $\begin{array}{c}\text { Nama diri dalam } \\
\text { bahasa sanskerta }\end{array}$ & Prosentase \\
\hline Dyah... & 1 & - & - \\
\hline Pu... & 34 & 18 & $13 \%$ \\
\hline Pu...rama ni.. & 1 & 1 & $0,7 \%$ \\
\hline Si... & 36 & 17 & $12 \%$ \\
Si...rama ni... & 52 & 9 & $6,43 \%$ \\
Si...inang ni... & 6 & - & - \\
Sang... & 1 & 1 & $0,7 \%$ \\
Dapunta... & 1 & 1 & $0,7 \%$ \\
\hline
\end{tabular}

Keterangan : Tabel ini dibuat penulis berdasarkan data yang digunakan

Tabel 9. Uraian Etimologi nama diri berbahasa Sanskerta

\begin{tabular}{|c|c|c|c|}
\hline No. & Pejabat Tingkat & Garbha nama & Makna secara etimologi \\
\hline \multirow{9}{*}{1.} & \multirow{2}{*}{ Pejabat kerajaan } & \multirow{2}{*}{ pu wīrawikrama } & Wira : pahlawan \\
\hline & & & Wikrama : berdiri \\
\hline & & pu wariga & Varikā : ilmu kimia kuna \\
\hline & & pu asangā & Asangā : wewangian \\
\hline & & pu cakra & Cakra : roda, atribut dewa Wisnu \\
\hline & & pu çiwadhyāna & Çiwa : dewa Siwa; \\
\hline & & & Dhyāna : meditasi \\
\hline & & pu sūryya & Sūryya : dewa Surya, \\
\hline & & & ivatanal \\
\hline
\end{tabular}




\begin{tabular}{|c|c|c|c|}
\hline \multirow[t]{20}{*}{2.} & Pejabat watak & pu dhanada & Dhanada : pemberi kesejahteraan \\
\hline & & pu damodara & Damodara : nama lain dari Krsna \\
\hline & & pu ayuddha & Ayuddha : tak dapat dihalangi \\
\hline & & pu samudra & Samudra : lautan \\
\hline & & pu danu & Danu : nama raksasa \\
\hline & & pu gowinda & Gowinda : nama lain dewa Wisnu \\
\hline & & pu laksana & Laksana : nama tokoh india \\
\hline & & pu baka & Baka : nama lain dari Kuwera \\
\hline & & pu gupura & Gopura : gerbang \\
\hline & & pu samodaya & saṃdhāya : terkait dengan Budha \\
\hline & & pu rāghū & Raghu : nama leluhur Rama \\
\hline & & si sañjaya & Samjaya : kemenangan \\
\hline & & si cangka & Cangka : atribut dewa Siwa \\
\hline & & si pārthawa & Partha : nama leluhur Arjuna \\
\hline & & sang uttara & Uttara : arah mata angin \\
\hline & & si naitra & Netra : pemimpin, pemandu \\
\hline & & pu kaiçawa & Kaiçawa : nama lain dewa Wisnu \\
\hline & & si çala rama ni barubuh & sala : air \\
\hline & & $\begin{array}{l}\text { si sangkhara rama ni } \\
\text { widyū }\end{array}$ & Samkhara : nama lain dewa Siwa \\
\hline & & si prajña & Prajña : pandai \\
\hline \multirow[t]{6}{*}{3.} & Pejabat Wanua & si mula rama ni buddhi & $\begin{array}{l}\text { Mūla : awal, asli } \\
\text { Buddhi : pandai }\end{array}$ \\
\hline & & si kabya rama ni sima & Sima : seluruh, semua \\
\hline & & si mangga rama ni garga & Garga : nama mahkluk mistis \\
\hline & & si sādha rama ni dhūta & $\begin{array}{l}\text { Sādha : bersama, makmur } \\
\text { Dūta : utusan }\end{array}$ \\
\hline & & si jabwah inang ni çuddha & Çuddha : murni, bersih \\
\hline & & $\begin{array}{l}\text { si sangkhara } \\
\text { si janar }\end{array}$ & $\begin{array}{l}\text { Samkhara : nama lain dewa Siwa } \\
\text { Janar : pelindung }\end{array}$ \\
\hline \multirow[t]{2}{*}{4.} & Non pejabat & si wangun rama ni wira & Wira : pahlawan \\
\hline & & si mala & Mala : rangkaian bunga \\
\hline
\end{tabular}

Sumber : Arthur A. MacDonnel, 1893

DISKUSI DAN PEMBAHASAN

\section{Perspektif Identitas}

Di dalam kajian ini nama diri yang menggunakan kosakata bahasa Sanskerta diperlakukan sebagai tanda budaya. Sebagai tanda, nama diri memiliki makna yang merepresentasi suatu bagian wawasan jagad atau world view, yakni cara manusia memandang kosmos 'alam semesta' dan lingkungan sosial budayanya melalui perilaku dan ide-idenya yang dituangkan dalam bentuk nama diri. Bertitik tolak dari konteks pemaknaan tersebut muncul identifikasi personal sebagai bagian dari sebuah kelompok sebagai bagian dari masyarakat Jawa Kuna abad ke-10 Masehi. Nama diri bukan

sekadar tersurat, namun dibalik itu ada hal-hal yang tersirat.

Perspektif identitas sering dimaknai sebagai definisi diri yang berkaitan dengan genealogi, status kewarganegaraan, sejarah bersama, 
kesatuan agama dan berbagai kesamaan (Meskell \& Preucel, 2007: 121). Di dalam memandang data arkeologi dengan perspektif identitas harus tetap memperhatikan konteks yang lebih luas yakni struktur sosial serta interaksi yang terjadi (Stets and Serpe, 2016:2).

Data berupa nama diri yang dituliskan di dalam Prasasti Poh terlihat adanya struktur sosial yang terwujud di dalam pembagian jabatan yang terbagi menjadi 3 yakni pejabat tingkat kerajaan, pejabat tingkat watak dan pejabat tingkat wanua. Selain itu masih terdapat lagi beberapa orang yang bukan sebagai pejabat tetapi turut sebagai saksi (rāma tpi siring milu sākçī ring manuçuk), yakni para rama marata dan seniman. Di dalam penyajian urutan daftar saksi yang menerima pasek-pasek dalam Prasasti Poh juga telah menunjukkan struktur yang dimulai dari Sri Maharaja sebagai orang yang terpenting dalam acara ini yang kemudian diakhiri oleh para rama dari desa sekeliling dan beberapa seniman yang diikutkan sebagai saksi.

Pada Tabel 7 terlihat bahwa pejabat tingkat watak mempunyai prosentase lebih tinggi di dalam pemakaian frase Bahasa Sanskerta dalam nama diri, yakni 20 orang $(14 \%)$ dari keseluruhan yang berjumlah 47 orang. Berdasarkan konstruksi terlihat jika nama diri yang dipakai adalah berupa wujud dasar, yakni dengan menggunakan kata atau nama dasar (monomorfemis). Hal tersebut sangat berbeda apabila dibandingkan dengan masyarakat Jawa Modern yang penggunaan nama dirinya berwujud kompleks (polimorfemis) yakni nama dasar yang diberi imbuhan morfem lain.

Bentuk dasar dari nama yang dipakai antara pejabat kerajaan dan watak dengan pejabat wanua juga menunjukkan gejala yang menarik. Untuk nama diri pejabat kerajaan dan watak terlihat menggunakan frasefrase kongkret nama tokoh yang berakar dari mitologi agama Hindu dan Buddha seperti Suryya, Laksana dan Raghu. Konstruksi yang lain adalah penggabungan dua frase yang lebih kompleks semacam Wirawikrama dan Çiwadhyāna. Pilihan frase maupun konstruksi nama para pejabat kerajaan dan watak menunjukkan pilihan-pilihan frase yang bermartabat.

Lain halnya dengan pejabat tingkat wanua yang lebih memilih frase-frase yang bersifat general seperti Buddhi, Suddha dan Mala. Terdapat satu hal yang menarik adalah terlihat di dalam nama diri Sri Maharaja yang menggunakan garbhanama khas Jawa Kuna, yakni Dyah Balitung. Secara leksikon frase "balitung" tidak memiliki makna namun ia tetap menggunakannya sebagai nama diri penguasa Mataram Kuna. Meski demikian Dyah Balitung untuk menunjukkan identitas yang berbeda dalam puncak stratifikasi sosial adalah dengan menggunakan gelar abhisekanama yang merupakan gambaran perwujudan dewa ke dalam tubuh raja yang menguasai kerajaan sebagai bagian makrokosmos.

Nama diri yang dijumpai di dalam Prasasti Poh apabila diasumsikan sebagai garbhanama yang tetap dipakai semenjak pertama kali diberikan oleh sang orang tua sewaktu bayi hingga dewasa (menjadi pejabat), maka pemilihan dengan menggunakan Bahasa Sanskerta secara langsung juga berpengaruh pada makna yang dipilih atas nama diri mereka. Pejabat watak sejak lahir diidentifikasikan sebagai komunitas keluarga raja yang secara struktural dan perseptual dekat dengan raja 
sebagai perwujudan dewa, sehingga nama diri yang dipilih untuk mendefinisikan dirinya adalah sebagai bagian inti kosmos 'alam semesta' yakni lingkungan kerajaan sebagai pusat persentuhan dan perkembangan pengaruh India dengan agama Hindu dan Buddha.

Demikian sebaliknya di kalangan pejabat wanua yang pada dasarnya bukan kerabat raja serta secara lokasi jauh dari pusat kerajaan, intensitas penggunaan Bahasa Sanskerta di dalam nama diri sangat jarang. Di kalangan pejabat wanua dan non pejabat yang turut hadir dalam upacara hanya dijumpai 9 orang dengan menggunakan nama diri dengan unsur Bahasa Sanskerta dari keseluruhan 77 orang yang hadir (lihat Tabel 7). Pemilihan secara leksikal pun dipilih makna yang lebih bersifat umum dan abstrak. Selain itu dari nama pejabat wanua dan saksi nonpejabat terlihat masih menganut konsep asli Jawa Kuna (atau Austronesia) yakni menggunakan formula "rama ni" atau "inang ni". Hal tersebut juga terlihat dengan penggunaan nama diri yang tidak memiliki makna leksikal dalam bahasa Jawa Kuna. Meski demikian nama semacam itu dipahami secara komunal oleh masyarakat masa itu.

Telah dipahami bahwasanya

pejabat watak berada pada stratifikasi kedua setelah pejabat kerajaan. Mereka pada umumnya juga masih kerabat raja (bangsawan) yang mempunyai kewenangan di daerah dalam struktur birokrasi kerajaan Mataram Kuna. Para pejabat watak ini pada saat itu adalah orang-orang middle range di dalam menerima dan menyerap pengaruh India. Edi Sedyawati (1986) mengatakan bahwa dominasi oleh kaum bangsawan dalam hal penerimaan pengaruh India dapat dikaitkan dengan asumsi bahwa budaya India pertama kali merasuk pada kalangan rajya yang kemudian mengembangkan budaya dengan berorientasi kepada pergaulan internasional (Sedyawati, 1986:36). Sebagaimana telah diuraikan di bagian awal bahwa bahasa Sanskerta lebih dipakai dalam situasi resmi keagamaan dan dipelajari oleh orang terpelajar setidaknya paham akan baca tulis. Dengan melihat jabatan watak tersebut terdapat beberapa jabatan citralekha dan parujar yang merupakan jabatan yang menuntut kemampuan untuk baca tulis. Sehingga dari hal ini terlihat jika perolehan kosa kata dari Bahasa Sanskerta yang kemudian dipakai sebagai nama diri adalah dari aktivitas pendidikan.

Di dalam pemilihan nama oleh orang tua secara umum dapat dilakukan secara arbitrer dan nonarbitrer. Arbitrer adalah penamaan sekadar untuk membedakan dengan orang lain dan nama itu tidak diketahui asal muasal maknanya. Hal ini dalam prasasti dapat dilihat untuk nama-nama yang menggunakan kosa kata Bahasa Jawa Kuna yang tidak memiliki makna leksikal. Meski demikian ia tetap memiliki makna bagi pemberi dan pemilik nama. Makna sebuah nama bagaimanapun sederhananya sangat berarti sehingga seseorang mengabadikan dalam nama.

Penamaan secara non arbitrer adalah memilih yang kata yang merupakan bagian dari tuturan atau kadangkala memiliki padanan dengan kosakata bahasa lain yang mengandung tujuan, harapan, citacita serta menggambarkan aspek historisitas. Sehingga umumnya penamaan semacam ini dijumpai maknanya secara leksikal. Melalui penguraian secara etimologis terhadap nama diri yang berasal dari bahasa Sanskerta juga dapat 
diketahui perbedaan pilihan kosakata yang dipakai oleh pejabat watak maupun pejabat wanua.

Pemberian nama merupakan salah satu upaya seseorang (orang tua) di dalam memandang dunianya yang dapat mengkomunikasikan antara alam pikiran, cita-cita, atau bahkan perkembangan lingkungan sosialnya. Salah satu contoh yang menarik terlihat adalah dari penggunaan nama yang dipakai oleh pejabat wanua yang secara eksplisit menunjukkan adanya perubahan budaya dalam memilih nama untuk anaknya. Seperti dalam nama si jabwah inang ni çuddha yang dengan jelas nama jabwah adalah nama asli Jawa Kuna yang tidak ada makna leksikalnya, sedangkan dia (si Jabwah) mempunyai anak yang dinamai dengan çuddha yang bermakna murni atau bersih. Dapat diperkirakan bahwa orang tua memberi nama dengan menggunakan kata Bahasa Sanskerta adalah terkait erat dengan motivasi dan dorongan, pola pikir dan respons budaya baru di dalam masyarakat.

\section{KESIMPULAN}

Penelitian lebih luas terhadap prasasti-prasasti yang berasal dari masa yang lebih tua dapat dipakai untuk melacak kembali bentukbentuk perkembangan pengaruh Hindu dan Buddha pada masyarakat biasa (non-pejabat) pada masa Jawa Kuna. Perkembangan tersebut dapat terefleksikan melalui pemakaian nama diri, baik itu yang mencirikan keaslian Jawa Kuna hingga pengaruh India. Nama diri tidak hanya menjelaskan arti atau makna secara leksikal saja, tetapi dapat menjadi ancangan penjelasan yang erat kaitannya dengan konteks sosial yang melingkupinya. 


\section{DAFTAR PUSTAKA}

Christie, Jan Wisseman,1989a, "Raja dan Rama : Negara Klasik di Jawa Masa Awal ", dalam Lorraine Gesick ( ed.), Pusat, Simbol dan Hirarki Kekuasaan, Jakarta: Yayasan Obor Indonesia.

Christie, Jan Wisseman, 1989b, "Wanua, Thani, Paraduwan: The Disintegrating Village in Early Java". Dalam Wolfgang Marschall (ed). Proceeding of the 7th European Colloqium on Indonesian and Malay Studies. Bern : Institut für Ethnologie.

De Casparis, J.G, 1986, "Some Aspects of Proper Names in Ancient Java", dalam CD. Grijns and S.O.Robson (eds), Cultural Contact And Textual Interpretation: Papers From The Fourth European Colloquium On Malay And Indonesian Studies, Held In Leiden In 1983, hlm. 8-18. Dordrecht/Cinnaminson: Foris. KITLV, Verhandelingen 115.

Digitalcollections.universiteitleiden.nl. (2019). OD-14439 / Digital Collections. Diunduh dari: https://digitalcollections.universiteitleiden.nl/view/item/8009 (Diakses 11 Jan. 2019).

Digitalcollections.universiteitleiden.nl. (2019). OD-14450 / Digital Collections. Diunduh dari: https://digitalcollections.universiteitleiden.nl/view/item/8087

(Diakses 11 Jan. 2019).

Kosasih, Dede, 2010, Kosmologi Sistem Nama Diri (Antroponim) Masyarakat Sunda: dalam Konstelasi Perubahan Struktur Sosial Budaya, Makalah disajikan dalam Seminar Internasional "Hari Bahasa Ibu" dengan tema: "Menyelamatkan Bahasa Ibu sebagai Kekayaan Budaya Nasional" di Gedung Merdeka tanggal 19-20 Februari 2010

MacDonnel, Arthur A, 1893, Sanskrit-English Dictionary, New York : Longmans Green and Co

Magli, Giulio, 2009, Mysteries and Discoveries of Archaeoastronomy From Giza to Easter Island, New York: Copercinus Books

Mahsun, 2010, Genolinguistik: Kolaborasi Linguistik Dengan Genetika Dalam Pengelompokan Bahasa dan Populasi Penuturnya. Yogyakarta : Pustaka Pelajar

Meskell, Lynn and Preucel, Robert W.(Ed), 2007, A Companion to Social Archaeology, New Jersey : Blackwell Publishing Ltd.

Rahardjo, Supratikno, 2011. Peradaban Jawa Dari Mataram Kuno Sampai Majapahit Akhir, Jakarta: Komunitas Bambu 
Schimmel, Annemarie, 1989, Islamic Names, Edinburg : Edinburg University Press.

Sedyawati, Edi, 1986, “ Kajian Kuantitatif Atas Masalah Local Genius ”, dalam Pertemuan Ilmiah Arkeologi IV 3-9 Maret, Cipanas

Stets, Jan E. And Serpe Richard T. , 2016, New Directions in Identity Theory and Research, New York : Oxford University Press

Stutterheim, W. F, "Oorkonde van Balitung Uit 905 A.D (Randoesari I)", dalam INI 1, 1940, hal. $4-7$.

Tjahjono, Baskoro Daru dan Rangkuti, Nurhadi, 1998, "Penetapan Sīma Dalam Konteks Perluasan Wilayah Pada Masa Klasik : Kajian Berdasar PrasastiPrasasti Balitung (899-910 M) ", dalam Berkala Arkeologi, th XVIII, Balai Arkeologi Yogyakarta.

Widodo, Sahid Teguh, 2001. "Nama Diri Masyarakat Jawa". Disertasi. Universitas Sebelas Maret. Surakarta

Zabeeh, Farahang, 1968, What Is In A Name: An Inquiry into The Semantics and Pragmatics of Proper Name, The Hague: Martinus Nijhoff 